\title{
THE NIRVANOL TREATMENT OF CHOREA
}

\author{
BY \\ WALTER M. WHITAKER, M.D. \\ House Physician, East London Hospital for Children.*
}

Various methods and drugs have been used in the treatment of chorea minor in children; among them are sodium salicylate, liquor arsenicalis, arsphenamine, bromides, milk injections, magnesium sulphate, thyroid extract, luminal, chloretone, and adrenalin subcarbonate. Medical literature reveals a percentage of good results from each of them, but since chorea is a more or less self-limited disease, a certain amount of scepticism accompanies any claim of cure.

One of the more recent and judging from the favourable foreign reports, most successful modes of therapy is nirvanol, a hypnotic which was first introduced for the treatment of chorea by Freda Roeder ${ }^{1}$ in 1919. Poynton and Schlesinger ${ }^{2}$ reported favourable results in six cases during 1929. Apparently these are the first to be reported in English literature, though Cunningham ${ }^{3}$ at the Strong Memorial Hospital at Rochester, New York, treared about a dozen cases of chorea in 1928 with favourable results. These, to date he has not published.

During the past few months (April to September 1929) it has been the writer's good fortune to treat eleven cases of chorea with nirvanol. These were in the wards of the East London Hospital for Children under the care of Drs. Geoffrey Bourne, Batten, Simpson, and Chodak Gregory, to whom I am indebted for permission to publish them. The favourable results in these cases, and the sparse English literature on the subject, are the reasons for their publication. It is also hoped that others will be stimulated to investigate further this mode of therapy.

Nirvanol is a white tasteless powder which is chemically phenylethylhydantoin having the formula :<smiles>CCCC(=O)NC(=O)NC(CC)(CC)c1ccccc1</smiles>

Luminal is closely allied to this but has one more CO group. Nirvanol belongs to the barbituric acid group, and not only has their usual hypnotic action but also seems to possess the power of producing a febrile reaction and an exanthem more often than any other known drug of the kind when given over continued periods. To this exanthem and enanthem de Rudder ${ }^{4}$ has given the name ' nirvanol sickness' The intensity and completeness of nirvanol sickness varies in different cases. The curative effect in chorea is apparently due to the bodily reaction produced by the sickness.

\footnotetext{
* Under the Reciprocity Scheme with Barnes Hospital, St. Louis, U.S.A,
} 


\section{The production of nirvanol sickness.}

To produce nirvanol sickness, the drug is given orally in a dosage of $\mathbf{0 . 3}$ grm. per day to children of 3-14 years of age until the appearance of an exanthem or enanthem, or both. This interval of time in most cases is from 7 to 14 days after the onset of administration. Usually the exanthem takes the form of a morbilliform rash which is often accompanied by pyrexia. Before the onset of the fever and rash, in many cases drowsiness is noted for 2-4 days. In the eleven cases here reported, so often was this present that it was possible to predict the imminence of the reaction by the degree of drowsiness present three or four days after beginning the drug. With the onset of any signs of nirvanol sickness, the drug is discontinued. Rest in bed is ordered during the administration.

Recognition of the rash may entail a close search. Usually it appears first on the torso and elbows; then in a few hours it has become generalized, probably involving the palms of the hands and the soles of the feet. It is most often of a morbilliform character, remains discrete, but sometimes becomes confluent on the elbows or knees. Of the reported cases all but one were of the morbilliform type, though urticarial and scarlatiniform varieties are known. Case 2 showed a discrete, blotchy, urticarial rash on one arm only. In general the face seems to escape the eruption but often shows a marked erythema and circumoral pallor. Case 11 approached a scarlet type. Desquamation was noted in those cases showing a severe reaction. Accompanying the rash in most cases is a raised temperature $\left(103-104^{\circ}\right)$ and a rise of pulse rate to perhaps $\mathbf{1 4 0}$ for three or four days. Usually the rash and fever subside simultaneously. There is often a complaint of headache, burning eyes, ouca. sional diplopia, mild sore throat, and œdema of the face has been seen. No œdema was noted in the present series but headache and conjunctivitis were common. There was no vomiting, but this symptom may oscur. Cases may remain afebrile throughout the course and yet develop a marked rash; as occurred in Cases 5 and 10; or may show no rash but have a fever as in Case 6 ; or may show neither a rash nor fever as occurred in Cases 4 and 9 . But in general the pyrexia seems proportional to the severity of the rash.

Some observers have considered it useless to administer the drug longer than for a period of 14 days (de Rudder ${ }^{4}$, Huber $^{5}$ ), but in two of the Shadwell cases no symptoms of nirvanol sickness were noted till the fifteenth day in Case 6, and the seventeenth day in Case 5. The standard dosage of $0.3 \mathrm{grm}$. per day had been given. In Case 4 the drug was given continuously for twentytwo days before signs of nirvanol sickness appeared and at this time the child complained of diplopia. It would seem from the present series that those cases which react within 7-12 days show the most marked symptoms of the sickness and this opinion is held by Lichentritt, Lengsfeld, and Silberberg ${ }^{6}$. Lesigang ${ }^{7}$ reports one case in a hundred that reacted with exanthem to a single dose.

Following the cessation of the sickness, or during it, there is noted a diminution in the movements. This may be almost dramatic in its suddenness, but in the Shadwell cases the improvement tended to occur within the 
first week or ten days, and there was in some cases complete loss of chorea within such a time. Many of these patients lose their gross bodily movement but retain the finer movements (e.g., tremor of hands) for several weeks after the reaction. If chorea is the result of an organic cerebral lesion this is not surprising, for no drug can be expected to remove rapidly both the cause of a disease and the gross local structural damage. Secondary reactions have occurred several days after the sickness with a return of the rash and fever. Keller $^{8}$ has suggested that these may have been due to exposure to the sun. Two of our patients were exposed to direct sunlight for three or four hours daily for five days during the first week after their reaction, and neither of them showed any signs of relapse.

Cases apparently resistant to nirvanol are met, in which neither rash nor fever occurs. There were two such cases in this series. In them, examination of the blood is very important, since Poynton and Schlesinger ${ }^{2}$ suggest that eosinophilia may at times be the only evidence of nirvanol sickness. De Rudder tried to induce serum sickness in two of his cases that were resistant to nirvanol, by giving repeated doses of serum over a period of several days but both failed to show any signs of serum sickness, so he suggested that such cases were immune to anaphylaxis. Such a statement seems illogical.

In the two Shadwell cases which failed to exhibit an exanthem and enanthem, the administration of $10-20$ million of killed B. typhosus intravenously, resulted in a reaction consisting of a temperature and pulse rise $6-12$ hours later. So these patients do not seem immune to protein shock.

Among the changes in the blood in nirvanol sickness the most common finding is that of an eosinophilia about the height of the reaction. Within two weeks in all cases the eosinophil count had returned to about the same percentage as had been found on admission. Several observers have stressed the presence of an eosinophilia in chorea. Cabot' found the blood normal in chorea except for increased eosinophils in twelve cases. Berger ${ }^{10}$ reported forty cases with a general average of 7.6 per cent. and found no relation between the severity of the chorea and the percentage of eosinophils. In the cases here reported six out of ten cases showed an eosinophilia on admission, considering 2 per cent., or about 120-140 eosinophils per c.mm., as the upper limit of normal. With nirvanol eight out of eleven cases showed a definite further increase, the total eosinophil figures in all the cases seriatim at the height of the reaction were, $350,0,750,300,520,140,780,1,050,550,2,330,90,260$ and 1,060 per c.mm. If there was no obvious reaction as evidenced by absence of fever or rash, then the blood was ex nined when the drug was suspended. In Cases 4 and 9 in which no exanthem or enanthem appeared, there was it the end of 22 and 17 days of administration respectively, an eosinophilia sf 280 and 550 per c.mm. These children did definitely improve and one is ead to believe that the eosinophilia was the only sign of a reaction. This confirms Poynton's and Schlesinger's suggestion as to the importance of watching the blood picture. These two cases also showed a relative lymphocytosis on the cessation of the drug with a decrease in the polymorphonuclears, a change 
also described elsewhere as occurring during the reaction ; but there were only three cases out of eleven in which there was found a relative lymphocytosis at the time of reaction. From this series therefore not much stress could be placed upon the constancy of a relative lymphocytosis, although it may perhaps be of value in ascertaining whether or not a reaction has occurred.

In ten cases at the height of the reaction, the polymorphonuclear cells were increased above the admission figures in four cases, decreased in three cases, and virtually the same in three cases.

During the administration of the drug the desirability of watching for a leucopenia has also been stressed; but the lowest leucocyte count recorded in our series was 4,800. Six out of ten cases at the height of the reaction showed a figure slightly reduced from that of admission, three were unchanged and only one (Case 2) showed a figure definitely higher than that of admission. This may be explained in Case 2 by the presence of a recent tonsillar infection a few days before starting to administer the drug, which may have served to elevate the count (the admission count was done two weeks before the drug was started).

Cases 3, 8, and 10 which showed the most marked eosinophilia did not seem to make a more rapid recovery than the other cases, in fact, the most speedy recovery occurred in Case 11 which showed only 88 eosinophils per c.mm. at the reaction time. From these few observations it seems that the degree of eosinophilia is of little value in prognosis as to the rate of recovery, but that eosinophilia itself is a very common sign of the sickness. Those cases showing a definite general reaction as evidenced by rash and fever with or without an eosinophilia seemed to improve the most rapidly, but Cases 4 and 9 did definitely improve without.

In no case were there any urinary findings of an abnormal nature during the cojurse of nirvanol administration or subsequently.

Examination of the red blood cells and hæmoglobin on two cases two weeks after the reaction showed no alteration. No changes were noted in the cardiac status during the treatment of those three cases $(1,2$, and 3$)$ showing cardiac lesions.

Cases 12 and 13 were two convalescent children in whom nirvanol was tried, merely as controls. They developed the usual effects. Case 12, a case of catarrhal jaundice, developed a typical rash with fever and increase in pulse rate, after eight days of administration, which lasted for five days with an eosinophilia of 260 per c.mm. Case 13 was convalescent from lobar pneumonia, and was completely recovered when given nirvanol. A reaction occurred on the eighth day with a typical nirvanol rash and fever, and an eosinophilia of 1,060 per c.mm. In both cases there were no obvious differences from the reaction which occurs in chorea cases.

\section{Action of nirvanol.}

Some interesting ideas have been advanced as to the manner in which nirvanol is able to produce its bodily effects. Biologically, de Rudder considered the reaction produced by the drug as being closely allied to serum sick- 
ness and that the success of the drug lay in the fact that during its administration a blood alkalosis was induced with a sudden shift to acidosis at the time of the reaction, the abrupt change having an effect on the central nervous system. Poynton and Schlesinger ${ }^{2}$ in two of their six cases studied the blood-plasma bicarbonate and noted an increase in the plasma bicarbonate in both cases during administration of the drug, but could demonstrate no tendency to acidosis at any stage of the treatment.

Using the colorimetric method for determining blood $\mathrm{pH}$ as devised by Dr. H. A. Ellis of London, on five of the present series at the height of their reaction, the $\mathrm{pH}$ was very constant, ranging from $7 \cdot 25$ to $7 \cdot 4$, with three cases at $7 \cdot 3$. Since this is a colorimetric method it is of course liable to the error involved in such readings, but the normal range of the figures merely bears out the recognized constancy of the $\mathrm{pH}$ of the blood except in the terminal stages of disease. However, such figures are not conclusive that an acidæmia may not have existed, but it was apparently not of a sufficient degree to affect the $\mathrm{pH}$ noticeably.

Since nirvanol is primarily a hypnotic and acts essentially as a depressant to the central nervous system, it might be argued that the fever was of central origin; but Lesigang ${ }^{7}$ was able to show that antipyrin was without effect in shortening the duration of fever in two cases of nirvanol sickness. This tends to rule out the possibility of direct stimulation of the heat regulation mechanism by nirvanol. As the drug is primarily a depressant it is unlikely to stimulate the centre. Moreover the hypothesis takes no account of the constant latent period which precedes the fever. The pyrexia is not entirely dependent upon the presence of the exanthem for cases occur with rash and no fever whatever, and vice versa.

Nirvanol seems to act cumulatively, as was shown in the cases here reported by the increased drowsiness after a few days of administration. The two cases which did not react with a rash exhibited this effect, which may well be due to the hypnotic action of the drug. Lesigang 7 , who used nirvanol in 106 cases of chorea, pertussis, epiplepsy, and other conditions, noted the tendency to drowsiness in most of his cases.

The symptom-complex present in nirvanol sickness may be met in the administration of other drugs which produce rashes, but is more frequently elicited by nirvanol than by other drugs. The rare instances of exanthem production after one or two doses (such as may occur in one in fifty or a hundred cases) are likened to drug idiosyncrasy by Lesigang?. In these cases a rash results after the first known contact with the foreign substance, but true nirvanol sickness comes only after a rather set period of administration, that is, a series of contacts with the drug. So although the symptoms are comparable with idiosyncrasy, the mode of production is different.

Lesigang ${ }^{7}$ was able to induce fever and rash in eleven out of twelve cases, which had previously had typical nirvanol sickness 18-39 days before, by the exhibition of one dose of nirvanol $(0.3 \mathrm{grm}$.). In one child a reaction was induced six months after the initial sickness by one dose and again five months later, a total of eleven months after the original sickness, In three of our 
cases $(8,10,11)$, which alone were so tested, it was possible to induce fever, rash, and a pulse rise about $6-10$ hours after a single dose of $0 \cdot 3 \mathrm{grm}$. of nirvanol. The reaction evoked in such cases was of a very mild character as compared with the original sickness. Since the vast majority of cases do not react to a single dose of the drug and since the appearance of the reaction occurs in a fairly fixed manner after repeated doses, apparently the conclusion to be drawn is that the body-tissues have become altered by the previous doses, so that instead of the simple narcotic action which normally might result from one dose, a modified effect occurs, in reality an active sensitization of the body to nirvanol. The occurrence of such a reaction from one dose of the drug given several weeks after the initial nirvanol sickness, can hardly be due to any cumulative effect, since Lesigang ${ }^{7}$ mentions that a child given 0.5 grains of luminal three times per day for thirty-four days, showed evidence of tho drug in the urine for only eight days after ceasing administration, and being so closely allied to luminal, nirvanol is probably excreted at a similar rate. It would thus seem that the organism reacts as to a narcotic cumulatively for a certain period, usually $7-12$ days of dosage, and that it is then actively sensitized to the drug, nirvanol sickness developing, so that the administration of a single dose several weeks after, will in most cases again induce signs of reaction.

That the rash and fever are more pronounced after $7-12$ days, than the same reaction induced by a single dose several weeks later, probably depends solely on the greater available quantity of nirvanol present when the initial reaction is induced. This seems borne out in Case 1 in which the.drug was not discontinued promptly on the appearance of symptoms but was given for three or four days after the rash appeared in 25 grain doses : the total febrile period was one of $9-10$ days which was a much more severe reaction than when the drug is discontinued promptly.

Lesigang ${ }^{7}$ thinks that nirvanol sickness is an allergic phenomenon rather than anaphylaxis as is maintained by de Rudder ${ }^{4}$. Lesigang bases his ideas on the criteria that anaphylaxis implies : (1) that the substance acting should be a protein antigen, (2) that passive transmissibility must exist, and (3) that acquired specific sensitivity is possible. He was unable to fulfill the second requirement when he had occasion to give a transfusion in which he took the blood from a child with nirvanol sickness and gave it to a two year old child, to whom he gave nirvanol in small doses but was unable to elicit a reaction. From its chemical formula, nirvanol is seen to be a non-protein antigen and according to Doerr ${ }^{11}$, anaphylactic phenomena can only be produced by protein antigens. So nirvanol sickness seems not to be due entirely to an accumulative effect, neither is it caused by idiosyncrasy or anaphylaxis; but it comes in that group of reactions known as allergic phenomena and which occur as intermediate gradations between the poles of idiosyncrasy and anaphylaxis (Diserr $\left.{ }^{11}\right)$.

The exact mechanism of the good effects produced in chorea still seems to be a puzzle. Cases appear to improve whether the marked signs of sickness, $:$ such as fever and rash, are or are not produced. Moreover, the eosinophiliac 
seems to be only a frequent accompanying factor. The hypnotic property must not be forgorten. Those cases having the most severe reaction do certainly seem to show the most marked and rapid improvement. Apparently then such a 'shake-up' of the body metabolism does in some way, as yet unknown, alter the condition of the central nervous system and thereby produce an improvement in the chorea. There seems to be no evidence in the English literature to support the idea that a sudden shift in the acid-base balance of the blood is induced at the time of the reaction.

Further biochemical investigations and careful clinical observations are desired to ascertain how the beneficial effects are induced.

\section{Hints on therapy.}

It is obvious that the use of a drug like nirvanol which is sometimes capable of producing alarming symptoms should only be undertaken in a hospital or in carefully controlled practice, but in this series no alarming symptoms were noted at any time. Leucopenia seems rare but the blood should be watched for evidence of a falling lencocyte count, or eosinophilia, since the latter seems sometimes to be the only sign of a reaction. The drug should be given dailyin doses of $0.3 \mathrm{grm}$. till a reaction or signs of toxicity occur and then omitted. To a child 13-14 years old, 0.6 grm. may be given. Treatment seems worth continuing for 15-20 days before stopping. An approaching reaction may be guessed by the presence of drowsiness after 3 or 4 days of the drug. The child should be kept at strict rest in bed during the treatment.

Before nirvanol was used in 1919 for chorea, it had been used as a hypnotic in adults in whom it often reacts more quickly and more sharply, though a rash was more rarely seen?.

Majerus ${ }^{12}$ described a fatal case of acute hemorrhagic nephritis associated with a severe bullous exanthem which he attributed to nirvanol, but it must be noted that this patient had a streptococcal empyema of four weeks dura. tion. Hæmaturia has been reported. Matzdorff ${ }^{13}$ recorded a case of toxicity without an unduly high dosage in which the child became comatose without an exanthem, but recovered shortly.

Such instances serve to demonstrate the potency of the drug, and to point to the necessity of careful observation during therapeusis, but certainly in the vast majority of cases the unpleasant signs and symptoms are insufficient to cause much distress either to the patient or the clinician. The good results of the cases treated in Germany by Huber $^{5}$ (20 cases-18 definitely improved), Lesigang ${ }^{7}$ (31 cases,most of which were definitely improved), Keller ${ }^{8}$ (nine cases), and the cases of Matzdorff ${ }^{13}$, F. Roeder ${ }^{1}$, Rietschel, and others are all evidence of the success and extent to which this drug is being used in Germany.

\section{Conclusions.}

The nirvanol treatment has been tried in eleven cases of chorea minor and in two control cases. Signs of nirvanol sickness were induced in nine of the eleven cases, and if eosinophilia may be considered as sufficient evidence 
of a reaction when occurring alone, then all cases may be said to have reacted. Marked reactions occurred in two non-choreic children simulating those seen in chorea cases in all respects. The majority of the observed cases showed a marked lessening up to complete absence of active chorea within the first week after the reaction, and in all there was no active chorea one month later. Improvement appears to be greatest in the violent and paralytic cases, mild cases, with continuous slight movements, being less benefited. Post-choreic tic, with repetition of one or more definite movements may occur in spite of the treatment. No relapses were seen.

Nirvanol certainly seems worthy of a trial especially in the more severe cases of chorea. Its effect on the ultimate prognosis remains to be seen.

I am greatly indebted to Dr. Temple Grey of this Hospital for the translation of the German literature.

\section{REFERENCES.}

1. Roeder, F., Ther. Monatschr., 1919, XXXIII, 54.

2. Poynton, F. J. \& Schlesinger, B., Lancet, Lond., i, 1929, 267.

3. Cunningham, personal communication.

4. Rudder, de., Therapie der Gegenwart, 1928, LXIX, 170.

5. Huber, H. G., Med. Welt., 1928, II, 1609.

6. Lichtentritt, B., Lengsfeld, W., Silberberg, M., Jahrb. f. Kinder., Berlin 1928, CXXII, 12.

7. Lesigang, W., Monatschr f. Kinder., 1928, 289.

8. Keller, L., Deut. Med. Wchnshr., Leipsic, 1928, Nov.

9. Cabot, R., Clin. Exam. of Blood, Edition III, 313.

10. Berger, H., Amer. Dis. of Children, Chicago, 1921.

11. Doerr, Die Anapyhlaxie forschung, 1914-1921. Ergbn. Von Weichardt Bd. 5, 1922, S 71.

12. Majerus, Deutsche Ztschr. f. Nervenh., Leipsic 1928, LXIII, 312.

13. Matzdorff, K., Deut. Med. Wchnshr, Leipsic 1926, LII, 528. 
SyNopsis of NIRVANOL.

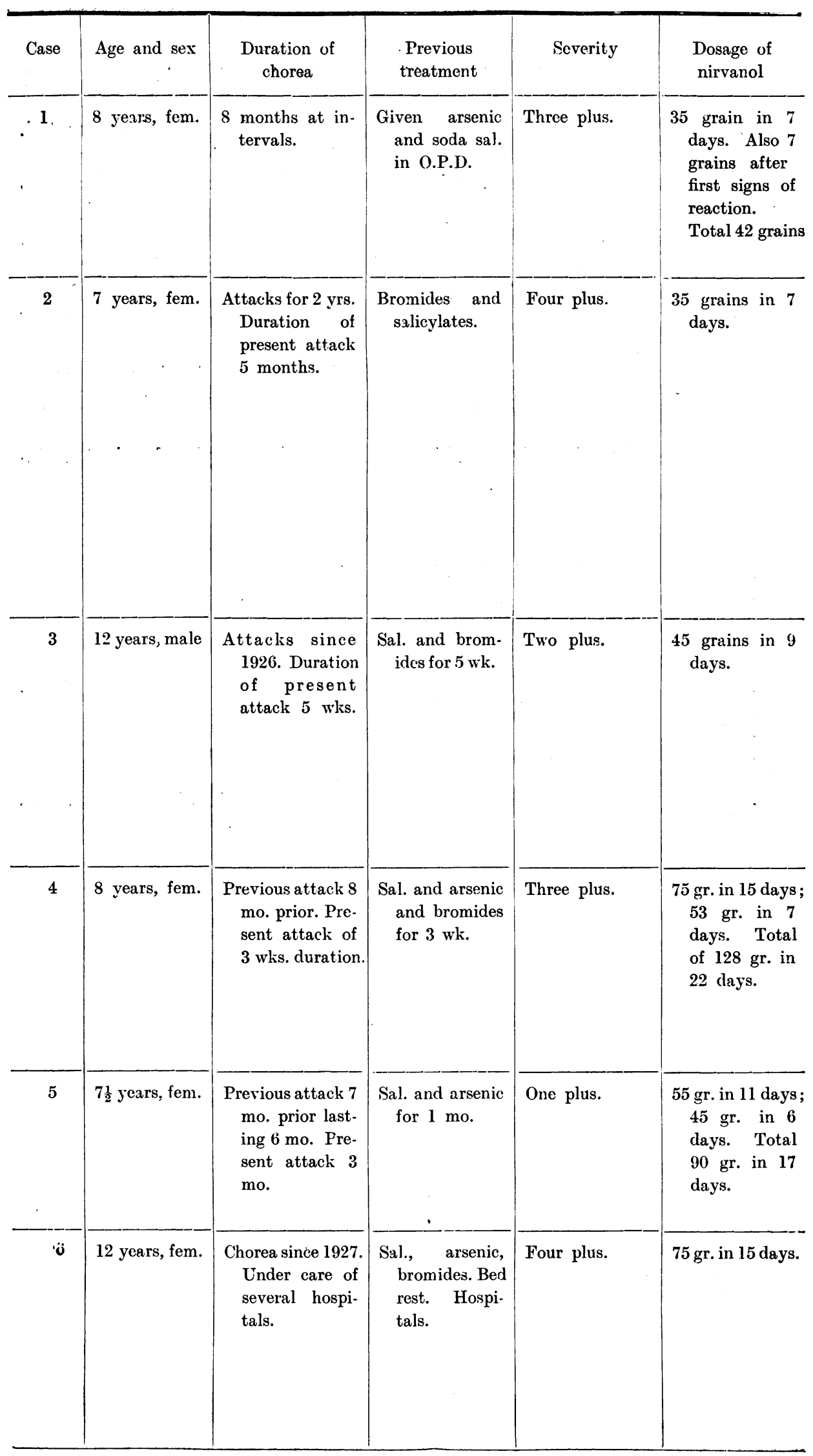




\begin{tabular}{|c|c|c|c|}
\hline $\begin{array}{l}\text { Symptoms of } \\
\text { "sickness", }\end{array}$ & $\begin{array}{l}\text { Height and } \\
\text { duration of fever }\end{array}$ & Progress & $\begin{array}{l}\text { Remarks and } \\
\text { results }\end{array}$ \\
\hline $\begin{array}{l}\text { Quieter after } 5 \text { days. } \\
\text { Drowsy. Temp. 103, } \\
\text { Pulse } 120 \text { on the } 7 \text { th } \\
\text { day. Rash } 8 \text { th day. } \\
\text { Lacrymation. Macu. } \\
\text { lo-erythematous rash } \\
\text { lasting 5-6 days. }\end{array}$ & $\begin{array}{l}103-104 \text { for } 6 \text { days. } \\
\text { Normal in } 10 \text { days. }\end{array}$ & $\begin{array}{l}\text { Less chorea at time of } \\
\text { reaction. } 2 \text { wk. after } \\
\text { the reaction, no ac- } \\
\text { tive chorea. In hos- } \\
\text { pital for } 6 \text { wk. (4 } \\
\text { wks. after reaction). }\end{array}$ & $\begin{array}{l}\text { Desquamated } 1 \text { mo. after } \\
\text { reaction. Heart lesion } \\
\text { unaffected. Gaining } \\
\text { weight. No active } \\
\text { chorea } 3 \text { months after. } \\
\text { Fine tremor of hand } \\
\text { persists. }\end{array}$ \\
\hline $\begin{array}{l}\text { T.P.R. rise on 7th day. } \\
\text { Blotchy discrete ery- } \\
\text { thema on right arm } \\
\text { and face. }\end{array}$ & $\begin{array}{c}\text { Temp. for } 4 \text { days. To } \\
103.5 \text { on first day. }\end{array}$ & $\begin{array}{l}\text { Tonsillitis } 10 \text { days prior } \\
\text { to drug. Drowsy } 1 \\
\text { day. Less choreic } 2 \\
\text { days after reaction. } \\
3 \text { wk. after reaction } \\
\text { had temp. to } 100 \text { and } \\
\text { blotchy rash of face } \\
\text { and torso for few } \\
\text { days associated with } \\
\text { a follicular tonsillitis. } \\
\text { In Hosp. } 15 \text { weeks. } \\
\text { Polys } 71 \% \text { Lym. } \\
23 \%, \text { Eosin } 3 \cdot 5 \% \\
\text { Monos. } 2 \cdot 5 \% .\end{array}$ & $\begin{array}{l}\text { Tonsillectomy } 5 \text { wk. after } \\
\text { the reaction. Progres- } \\
\text { sive improvement in } \\
\text { chorea, also in mental } \\
\text { stability. No move- } \\
\text { ments } 1 \text { mo. after } \\
\text { reaction. }\end{array}$ \\
\hline $\begin{array}{l}\text { After } 9 \text { days had a rash } \\
\text { on torso. No temp. } \\
\text { or pulse rise till loth } \\
\text { day. Generalized } \\
\text { morbilliform rash, } \\
\text { lasting one day, } \\
\text { followed by erythema } \\
\text { lasting } 3 \text { days. }\end{array}$ & To 100 F. for 4 days. & $\begin{array}{l}\text { Drowsy 3-4 days prior } \\
\text { to reaction. Less } \\
\text { chorea in 3rd wk. } \\
\text { Heart as before. Loss } \\
\text { of movements was } \\
\text { gradual. Marked im- } \\
\text { provement in men- } \\
\text { tality and general } \\
\text { appearance. In hos- } \\
\text { pital a total of } 6 \text { wk. }\end{array}$ & $\begin{array}{l}\text { Chorea gone when ob- } \\
\text { served } 1 \text { mo. after dis- } \\
\text { charge from hospital. } \\
\text { Slight œedema of ankles. } \\
\text { Sent to Bognor. No } \\
\text { relapse. }\end{array}$ \\
\hline $\begin{array}{l}\text { None, but diplopia and } \\
\text { burning of eyes after } \\
22 \text { days. No rash. }\end{array}$ & None. & $\begin{array}{l}\text { Drowsy after } 10-12 \\
\text { days. Definitely less } \\
\text { choreic after } 3 \text { wks. } \\
\text { of the drug. No } \\
\text { chorea when dis- } \\
\text { charged. In hospital } \\
7 \text { wk. (4 wk. after } \\
\text { the cessation of drug). }\end{array}$ & $\begin{array}{l}\text { Given } 20 \text { million killed } \\
\text { B. Typhosus intraven- } \\
\text { ously, } 2 \text { wk. after sus- } \\
\text { pension of drug. Prompt } \\
\text { fever and pulse rise. } \\
\text { No relapse. }\end{array}$ \\
\hline $\begin{array}{l}\text { Slight rash. No fever } \\
\text { Pulse to } 110 \text { on first } \\
\text { day. Rash morbilli- } \\
\text { form. Only on fore- } \\
\text { arms. Erythema of } \\
\text { face. }\end{array}$ & None. & 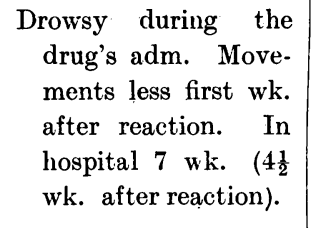 & $\begin{array}{l}\text { Movements gone } 1 \text { mo. } \\
\text { after reaction. }\end{array}$ \\
\hline $\begin{array}{l}\text { No rash. Fever and } \\
\text { pulse rise after } 15 \\
\text { days. }\end{array}$ & $100 \mathrm{~F}$. for two days. & $\begin{array}{l}\text { Movements sl. less prior } \\
\text { to reaction. Much } \\
\text { less } 3-4 \text { days after } \\
\text { reaction. No active } \\
\text { chorea } 1 \text { mo. later. } \\
\text { In hospital } 13 \text { wk. } \\
\text { (10 wk. after re- } \\
\text { action) Up for } 5 \text { wk. } \\
\text { before discharge. }\end{array}$ & $\begin{array}{l}\text { Considering the severity } \\
\text { of this case, improve- } \\
\text { ment was rapid and } \\
\text { excellent. The good } \\
\text { effects were noted with- } \\
\text { in a few days after the } \\
\text { reaction. }\end{array}$ \\
\hline
\end{tabular}


TABLE contd.

SYNopsis OF NIRVANOL-

\begin{tabular}{|c|c|c|c|c|c|}
\hline Case & Age and sex & $\begin{array}{l}\text { Duration of } \\
\text { chorea }\end{array}$ & $\begin{array}{c}\text { Previous } \\
\text { treatment }\end{array}$ & Severity & $\begin{array}{l}\text { Dosage of } \\
\text { Nirvanol }\end{array}$ \\
\hline 7 & 10 years, male & 5 wk. & $\begin{array}{l}\text { Bed rest at home } \\
\text { for } 4 \text { wks. } \\
\text { with no im- } \\
\text { provement. }\end{array}$ & $\begin{array}{l}\text { Two plus. } \\
\text { Speech affected. }\end{array}$ & $\begin{array}{l}35 \text { gr. in } 7 \text { days. } \\
22 \text { gr. in } 3 \\
\text { days. Total } \\
57 \text { gr. in } 10 \\
\text { days. }\end{array}$ \\
\hline 8 & $13 \frac{1}{2}$ years, male & $\begin{array}{l}\text { Chorea for } 3 \text { mo. } \\
\text { in past year. } \\
\text { Present attack } \\
\text { of } 2-3 \text { mo. } \\
\text { duration. }\end{array}$ & Negligible. & Two plus. & $\begin{array}{l}55 \text { gr. in } 11 \\
\text { days. }\end{array}$ \\
\hline 9 & 6 years, fem. & 9 months. & Negligible. & Three plus. & $\begin{array}{l}60 \text { gr. in } 12 \text { days. } \\
37 \mathrm{gr} \text {. in } 5 \\
\text { of } 97 \mathrm{gr} \text {. in } \\
\text { days. Total } \\
17 \text { days. }\end{array}$ \\
\hline 10 & $\begin{array}{l}5 \text { years, fem. } \\
\text { W }\end{array}$ & 1 wk. & None. & Three plus. & $45 \mathrm{gr}$. in 9 days. \\
\hline 11 & 9 years, male & $\begin{array}{l}\text { Had had } 3 \text { attacks } \\
\text { in past } 2 \text { yrs. } \\
\text { Present one of } \\
4 \text { wk. dura- } \\
\text { tion. }\end{array}$ & None. & Four plus. & 40 gr. in 8 days. \\
\hline 12 & 5 years, male & \multicolumn{3}{|c|}{ Convalescent catarrhal jaundice used as a control. } & 40 gr. in 8 days. \\
\hline 13 & 4 years, male & \multicolumn{3}{|c|}{ Convalescent lobar pneumonia used as a control. } & 40 gr. in 8 days. \\
\hline
\end{tabular}

One plus $(+)$.-Mild movements. No speech defects. Able to feed self.

'Two plus $(++)$.-Moderate degree of movements. Able to feed self.

Three plus $(+++)$.-Very marked movements. Emotional. Speech defects. Unable to feed self

Four plus $(++++)$-Bodily injuries from movements، Unable to feed self. Mental instabilities. Speech defects, 


\begin{tabular}{|c|c|c|c|}
\hline $\begin{array}{l}\text { Symptoms of } \\
\text { "sickness" }\end{array}$ & $\begin{array}{l}\text { Height and duration } \\
\text { of fever }\end{array}$ & Progress & $\begin{array}{l}\text { Remarks and } \\
\text { results }\end{array}$ \\
\hline $\begin{array}{l}\text { Morbilliform rash on } \\
\text { hands, and fever on } \\
\text { 10th day. Rash was } \\
\text { general on 11th day. } \\
\text { Pulse 110. Lacryma- } \\
\text { tion. Headache. }\end{array}$ & $\begin{array}{l}\text { Fever for } 4 \text { days. Peak } \\
102 \text { F. }\end{array}$ & $\begin{array}{l}\text { Drowsy } 2-3 \text { days be- } \\
\text { fore reaction. Defin- } \\
\text { itely less choreic and } \\
\text { speech unaffected, } \\
\text { the first wk. after re- } \\
\text { action. In hospital } \\
7 \text { wk. ( } 5 \text { wk. after } \\
\text { reaction). }\end{array}$ & $\begin{array}{l}\text { No active chorea } 10 \text { days } \\
\text { after reaction. Speech } \\
\text { normal. Gaining weight } \\
\text { Very slight fine tremor } \\
\text { of hands persists. }\end{array}$ \\
\hline $\begin{array}{l}\text { Fever. General morbilli- } \\
\text { form rash, head- } \\
\text { ache, pulse rise. Con- } \\
\text { junctivitis. }\end{array}$ & $\begin{array}{l}\text { Fever of } 102.5 \text { for } 4 \\
\text { days. } 100 \text { for } 1 \text { day. }\end{array}$ & $\begin{array}{l}\text { Drowsy } 2-3 \text { days prior } \\
\text { to reaction. Defin- } \\
\text { itely less choreic first } \\
\text { wk. thereafter. No } \\
\text { active chorea } 10 \text { days } \\
\text { later. No chorea one } \\
\text { mo. later. In hospital } \\
\text { for } 7 \text { wks. (5 wk. } \\
\text { after reaction). }\end{array}$ & $\begin{array}{l}\text { In sunlight for few hours } \\
\text { for } 5 \text { days without } \\
\text { relapse. Tonsillectomy } \\
2 \text { wks. after reaction. } \\
\text { nirvanol gr. V, } 3 \text { wk. } \\
\text { after reaction. Developed } \\
\text { slight rash on forearms } \\
10 \text { hrs. later. No chorea } \\
\text { on discharge. Nirvanol } \\
\text { gr. } 7 \frac{1}{2} \text { gave a temp. to } \\
99 \mathrm{~F} \text {. and a pulse of } 100 \\
\text { when given } 4 \text { wks. after } \\
\text { the initial reaction. }\end{array}$ \\
\hline None. No rash. & None. & $\begin{array}{l}\text { More quiet after } 2-3 \\
\text { days of drug. Move- } \\
\text { ments less during } \\
\text { adm. of drug and no } \\
\text { active chorea } 1 \text { wk. } \\
\text { after drug was ces- } \\
\text { sated. In hospital } 7 \\
\text { weeks. }\end{array}$ & $\begin{array}{l}\text { Definitely improved. } \\
\text { Given I.V. Typhoid one } \\
\text { wk. after drug was dis- } \\
\text { continued ( } 10 \text { million). } \\
\text { Reaction with temp. } \\
\text { and pulse rise a few } \\
\text { hours later. }\end{array}$ \\
\hline $\begin{array}{l}\text { Generalized morbilliform } \\
\text { marked rash. Most } \\
\text { marked on elbows } \\
\text { and knees. No fever } \\
\text { or pulse rise, till two } \\
\text { days after rash ap- } \\
\text { peared. }\end{array}$ & None. & $\begin{array}{l}\text { Drowsy } 2 \text { days prior to } \\
\text { reaction. Movements } \\
\text { less two days after } \\
\text { rash subsided. Stead- } \\
\text { ily improving. In } \\
\text { hospital5 wk. Chorea } \\
\text { developed during } \\
\text { child's convalescence } \\
\text { from pneumonia in } \\
\text { the hospital. }\end{array}$ & $\begin{array}{l}\text { Has definitely improved } \\
\text { but not so rapidly as } \\
\text { most of the other cases. } \\
\text { Given } 5 \text { gr. of nirvanol } \\
2 \text { wk. after her re- } \\
\text { action. Drowsy } 2-3 \\
\text { hr. later. Rash and } \\
\text { pulse rise } 10 \text { hrs. later. } \\
\text { No fever. Signs had } \\
\text { disappeared in 18-24 } \\
\text { hours. }\end{array}$ \\
\hline $\begin{array}{l}\text { Temp. and pulse up } \\
\text { followed by a general- } \\
\text { ized morbilliform } \\
\text { rash on 9th day. Was } \\
\text { giddy. Conjunctivitis. }\end{array}$ & 102-103 for 6 days. & $\begin{array}{l}\text { Drowsy } 2-3 \text { days prior } \\
\text { to reaction. Defin- } \\
\text { itely less chorea dur- } \\
\text { ing reaction. No } \\
\text { chorea } 1 \text { wk. after } \\
\text { reaction. Still in hos- } \\
\text { pital. }\end{array}$ & $\begin{array}{l}\text { Almost a dramatic re. } \\
\text { covery. Given } 5 \text { gr. of } \\
\text { Nirvanol } 1 \text { wk. after } \\
\text { reaction. Drowsy few } \\
\text { hours later. Rash and } \\
\text { fever } 8 \text { hrs. later. Temp. } \\
\text { to } 100.4 \text { for } 2-3 \text { days. } \\
\text { Pale rash for } 2 \text { days. }\end{array}$ \\
\hline \multirow[t]{2}{*}{$\begin{array}{l}\text { Temp. and pulse rise } \\
\text { with morbilliform } \\
\text { general rash. }\end{array}$} & $\begin{array}{l}\text { Fever for } 4 \text { days } 102.5 \\
\text { at peak. }\end{array}$ & & Uneventful recovery. \\
\hline & $\begin{array}{l}\text { Fever for } 2 \text { days. } 102 \\
\text { at peak. }\end{array}$ & & Uneventful recovery. \\
\hline
\end{tabular}

